\title{
Baby Corn Candy: Development and Assessment of Nutritional, Sensory and Storage Quality
}

\author{
D. Shobha*, M.S. Sreedevi and Puttaramanaik \\ Zonal Agricultural Research Station, V.C. Farm, Mandya-571405, Karnataka, India \\ *Corresponding author
}

\begin{tabular}{|l|}
\hline K e y w o r d s \\
Osmotic dehydration, \\
Blanching, \\
Rectangular candy, \\
MPP
\end{tabular}

\section{Introduction}

Baby corn (Zea mayz L.) is the small young ear before pollination and is an important vegetable product (Lekagul, 1994). Corn has wider adaptability, high yielding ability and fast growing habit and hence emerged as a potential alternative crop to diversify sustainable agriculture. In India baby corn production and processing industries are still in early stage which needs to be developed through combined efforts of producers, processers and consumers. Baby corn and its
The quality of baby corn candy prepared with four different sugar concentrations $\left(20 / 30 / 40^{\circ} \mathrm{B}, \quad 30 / 40 / 50^{\circ} \mathrm{B}, 40 / 50 / 60^{\circ} \mathrm{B}\right.$ and $\left.50 / 60 / 70^{\circ} \mathrm{B}\right)$ in two different shapes (Rectangular and Whole) was evaluated for acceptability and storage stability. The sensory scores of rectangular shaped candies prepared from $40 / 50 / 60^{\circ}$ brix scored between "like very much to like extremely" in terms of overall acceptability (8.2) compared to other treatments. Optimum sugar concentration of $40 / 50 / 60^{\circ}$ brix with 24 hours steeping resulted in water loss and solid gain of $32.25 \%$ and $7.33 \%$, respectively. The analyzed nutritional quality of $40 / 50 / 60^{\circ}$ brix rectangular candy is as follows; ash $(2.2 \%)$, fat $(0.5 \%)$, protein $(1.93 \%)$, crude fiber $(1.95 \%)$, carbohydrate $(86.0 \%)$, calcium $(24 \mathrm{mg})$, magnesium (85.33 mg), iron $(0.23 \mathrm{mg})$ and phosphorus $(64.13 \mathrm{mg})$ contents. From storage studies, it we the rectangular candy has better sensory traits when stored for six text in MPP pouches at ambient condition with good retention of flavor, taste and texture without any adverse effect on nutritional quality. Consumer acceptability for school children's conducted in three different locations at V.C. Farm, Hassan and Mandya indicated that maximum number $(82.2 \%)$ of consumers rated the candy as "very good" followed by good (11.1\%) and not good (6.6\%), respectively. 
However, baby corn cultivation is now picking up in Meghalaya, Western Uttar Pradesh, Haryana, Maharashtra, Karnataka and Andhra Pradesh (Kheibari et al., 2012). Majority of baby corn produced is going for raw cob consumption as a safe vegetable and it also finds place in most of the restaurants, hotels and motels as decorative crispy vegetable in salad, soup, pickles, pakodas, vegetable biryani, pasta, chutney, cutlets, chat, dry vegetable kofta, curry, manchurian, raita, jam, murabba, burfi, halwa, kheer, deep fried baby corn with meat, rice and other favorite dishes (Asaduzzaman et al., 2014).

Baby corn nutritive value is quite comparable to any other seasonal vegetable. Besides proteins, vitamins and iron, it is one of the richest sources of phosphorous and easy to digest. It is the most "safe" vegetable to eat as it is almost free from residual effects of pesticides due to wrapping of young cob with husk and well protected from insects and diseases (Kawatra and Sehgal, 2007). Baby corn can be consumed either raw or cooked. Processing of baby corn into value added and shelf stable products are needed as fresh corns begin to deteriorate quickly after harvest. In order to overcome this problem, timely harvesting of baby corns within 2-3 days of silk emergence $(1-2 \mathrm{~cm})$ is suggested. In spite of its popularity as a fresh vegetable in Asia, systematic research on the processing, preservation and storage behavior to extend the nutritional and agricultural potential of this crop is lacking. Since baby corn has typical bland taste huge scope exists for value added products. Various products can be prepared by adopting low cost technologies which in turn increase the income of farming community. Traditional low cost processing technologies are available for preservation of fruits and vegetables like drying, dehydration, pickling, brining, fermenting and osmotic dehydration. The most widely used method for preservation of fruits and vegetables is osmotic dehydration. During osmotic treatment several flows occur simultaneously; loss of water from the product to the hypertonic solution, solute impregnation from the solution to the food matrix and additionally, loss of other compounds (mainly soluble solids) from the product to the solution (Chenlo et al., 2002). Literature on osmotically dehydrated product preparation from fruits and vegetables is available in large numbers such as cashew apple, pineapple slices, West Indian cherry, pineapple cubes, tomato candy and ginger candy (Azoubel and Murr, 2003; Thakor and Sawant, 2008; Silva et al., 2012; Paul, 2014; Hasanuzzaman et al., 2014 and Patil et al., 2015), respectively. However, osmotic dehydration of baby corn with different ratios of sugar concentration and its acceptability as candy has not been studied. Hence, this study was taken up to assess the suitability of baby corn for candy preparation and its quality in terms of sensory, nutritional and microbial load.

\section{Materials and Methods}

Baby corns were harvested from the Experimental plots of the All India Coordinated Research Project on Maize, Zonal Agricultural Research Station, V.C. Farm, Mandya. The selected baby corns (two days after silk emergence) were de husked and the silk was removed by hand. The freshly harvested baby corns were analyzed for physical parameters such as length and breadth using Vernier calipers (Mitutoyo Digimatic Caliper) and weight of the corn with and without husk was weighed in grams using electronic weighing balance. The nutritional composition of fresh baby corn was analyzed as per Ranganna (2001).

\section{Preparation of baby corns}

For osmotic dehydrated candy preparation, two different shapes were made; Whole (W) 
baby corns were trimmed to get uniform sized corns of 7-8 cm length and 1.04-1.05 cm breadth and rectangular (R) pieces with $4.0 \mathrm{~cm}$ length and $1.04 \mathrm{~cm}$ breadth.

\section{Method of candy preparation}

Prior to osmotic dehydration, two types of corns (W and R) were weighed and subjected to hot water blanching three minutes along with addition of $0.2 \%$ sodium meta-bisulphate (KMS) to the boiling water.

To standardize the recipe for preparation of baby corn candy, the $\mathrm{W}$ and $\mathrm{R}$ baby corns were steeped in four different combinations of sugar concentrations $\left(20 / 30 / 40^{\circ} \mathrm{B}, 30 / 40 / 50^{\circ} \mathrm{B}\right.$, $40 / 50 / 60^{\circ} \mathrm{B}$ and $50 / 60 / 70^{\circ} \mathrm{B}$ ) for $24 \mathrm{hrs}$ in each concentration to facilitate osmosis by keeping the sample to solution ratio as 1:3.

Citric acid and KMS were added to osmotic solution at the rate of $0.05 \%$ to enhance the keeping quality of the candy. The osmosed baby corns were dried at $60^{\circ} \mathrm{C}$ for $8 \mathrm{hrs}$ to reach final moisture content of 10-11 per cent.

\section{Osmotic dehydration characteristics}

The pattern of osmosis in terms of weight reduction (WR), solid gain (SG) and water loss (WL) were determined for selected candy by employing equations provided by Patil et al., (2015).

Weight reduction $(\%)=\frac{\mathrm{W}_{2}-\mathrm{W}_{1}}{\mathrm{~W}_{1}}$

$$
\left(\mathrm{W}_{3}-\mathrm{W}_{1} \times\left(100-\mathrm{M}_{1}\right) / 100\right)
$$

Solid gain $(\% \mathrm{wb})=-\mathrm{-} \cdot \mathrm{W}_{1}$

Water loss $(\% \mathrm{wb})=\mathrm{WR}+\mathrm{SG}$

$\mathrm{W}_{1}=$ Initial weight of the sample $(\mathrm{g})$
$\mathrm{W}_{2}=$ Final weight of the sample after osmosis (g)

$\mathrm{W}_{3}=$ Oven dried weight of the sample after osmosis (g)

$\mathrm{M}_{1}=$ Initial moisture content of the sample before osmosis (\% wb).

\section{Sensory evaluation}

In order to select the best acceptable product, eight osmotically dehydrated candies (Rectangular candy; RC and Whole candy; WC) were subjected to sensory evaluation by semi trained judges. Panelists $(\mathrm{N}=21)$ were provided with coded samples along with glass of water and instructed to rinse and swallow water between the samples. Panelists were given written instructions and asked to evaluate the products for acceptability based on its appearance, color, taste (aroma and sweetness), texture and overall acceptability on nine-point hedonic scale (Amerine et al., 1965).

\section{Nutritional composition of baby corn candy}

Developed baby corn candies were assessed for nutritional composition as per Ranganna (2001).

\section{Storage study}

RC and WC were packed in MPP (Metalized Polyester Polyethylene laminate) pouches and stored under room temperature $\left(25-30^{\circ} \mathrm{C}, 65\right.$ $\% \mathrm{RH}$ ) for a period of six months to assess the shelf life of the products.

\section{Assessment of bio-chemical and sensory quality}

The parameters such as $\mathrm{pH}$, moisture, titrable acidity and ash (Ranganna, 2001) as well as acceptability of candy in terms of sensory 
parameters were assessed every month during storage (0-6 months).

\section{Analysis of nutritional composition}

Based on the biochemical and sensory quality, only one type of candy was taken for assessment of nutritional composition such as proximate, calcium and phosphorus (AOAC, 1995), carbohydrate and mineral contents (Livesey, 2001). Magnesium and iron contents were determined by Versanate titration and Wong's method, respectively. Vitamin C content in fresh baby corn and candies was analyzed by 2, 6-dichlorophenol indophenol titration method as quoted by Ranganna (2001).

\section{Microbial analysis}

Microbial load including bacteria, moulds and yeasts of stored candies were analysed according to APHA (1984) by drawing the samples every month.

Even the osmotic exudate (sugar syrup obtained after draining of baby corn) was examined every month for clarity, visual growth of microorganisms, changes in $\mathrm{pH}$ and TSS content.

\section{Consumer acceptability}

The best acceptable candy was distributed to school children $(n=30)$ at three locations such as V.C. Farm, Hassan and Mandya to elicit the consumer acceptability of the product by rating the product as "very good", "good" and "not good".

\section{Statistical analysis}

The data was subjected to ANOVA for preliminary sensory evaluation and nutritional composition studies while two-way ANOVA was used for storage study of two shapes of candies as per Steel et al., (1997) for determining the effect of storage on different quality parameters.

\section{Results and Discussion}

\section{Physical characteristics of fresh baby corn}

Physical characteristics of fresh baby corn revealed that the average weight of baby corn with husk, without husk and weight of husk and silk were in the range of 48.86, 8.06 and $40.80 \mathrm{~g}$, respectively. The average length and breadth of fresh baby corn were found to be 7.16 and $1.04 \mathrm{~cm}$, respectively. Similar results for length and breadth were reported by Aggarwal and Kaur (2010) for baby corn harvested after two days of silk emergence.

\section{Nutritional composition of fresh baby corn}

The nutritional quality of baby corn is presented in Table 1. The fresh baby corn had a moisture content of $86.41 \%$. The crude protein, fat, crude fiber, ash and carbohydrates were in the range of $2.90,0.90,3.42,1.34$ and 9.13 , respectively.

The mineral and energy contents in this study were in the range of $25.77 \mathrm{mg}$ for calcium, magnesium (85.87 $\mathrm{mg}$ ), phosphorus (84.10 $\mathrm{mg})$, iron (0.32 mg) and energy (56.55 k.cal). Our findings are in accordance with the values reported by Anuradha (2012) for carbohydrate, protein, calcium, phosphorous and iron contents in fresh baby corn.

\section{Development and osmotic dehydration characteristics of baby corn candy}

Prior to candy preparation, the baby corns were subjected to water blanching containing $0.2 \% \mathrm{KMS}$ solution for three minutes was found to be sufficient to retain the colour of the product. However, Aggarwal and Kaur (2010) reported four minutes water blanching 
time was optimum to retain the colour of the product which increase the permeability of the skin and prevent the browning reactions. On the contrary, Singh et al., (2007) reported blanching followed by dipping in $0.3 \%$ solution of KMS for 3 min helps to retain the colour and vitamins. Beneficial effect of blanching with KMS/sulphitation on retention of ascorbic acid content of dried product was also observed by many workers (Sethi, 1986; Tripathi et al., 1988; Sagar and Kumar, 2006; Singh et al., 2006b) which may be due to inactivation of oxidase enzyme.

After blanching, baby corns were steeped in four different sugar concentrations as depicted in Figure 1. As the sugar concentration increased, the water loss and solid gain also increased, but the increased solid gain $\left(50 / 60 / 70^{\circ} \mathrm{B}\right)$ resulted in too sweet candies which were not acceptable by the panelists. Hence, the optimum concentration of sugar was found in $40 / 50 / 60^{\circ} \mathrm{B}$ with $24 \mathrm{hrs}$ steeping resulted in $35.26 \%$ of water loss and $7.33 \%$ of solid gain.

The increase in water loss and sugar gain with increase in syrup concentration was due to increased osmotic pressure in the syrup which increased the driving force available for water transport. Similar results were noticed by Patil et al., (2015) for osmotically dehydrated ginger candy. This trend was also in agreement with potato (Biswal and Bozorgmehr, 1991) and banana slices (Pokharkar et al., 1997).

Highest moisture loss; over $50 \%$ of the initial moisture was removed in osmotic dehydration of cran-berries, reducing initial moisture content from $88 \%$ to a final $43.4 \%$ after osmotic dehydration of $24 \mathrm{hrs}$ in particular sugar concentration. Similar pattern was observed in this study. Steeping in osmotic solution for $24 \mathrm{hrs}$ was found to be optimum for good quality product yield in baby corn candy. Candies subjected to longer duration ( $>24 \mathrm{hrs}$ ) were darker in colour and emitted an unpleasant odour. Hence, in this study $24 \mathrm{hrs}$ period of steeping in each concentration (40, 50 and $60^{\circ}$ brix) was followed. The osmotic exudate (syrup) obtained after osmosis of baby corns can be used as juice by diluting with water in the ratio of 1:3.

\section{Effect of different sugar concentrations on sensory attributes of baby corn candies}

Perusal of Table 2 revealed that $\mathrm{WC}$ and $\mathrm{RC}$ prepared from $40 / 50 / 60^{\circ} \mathrm{B}$ sugar concentration $\left(\mathrm{T}_{6}\right.$ and $\mathrm{T}_{5}$ ) got significantly good sensory scores for the sensory attributes like appearance (8.25 and 7.25), colour (8.30 and 6.80), taste (8.5 and 6.7), flavor (8.87 and 7.0), texture (8.3 and 6.8) and overall acceptability (8.2 and 7.0) compared to rest of the treatments studied $\left(\mathrm{T}_{1}-\mathrm{T}_{8}\right)$.

The treatments with $20 / 30 / 40^{\circ} \mathrm{B}, 30 / 40 / 50^{\circ} \mathrm{B}$ of sugar concentrations were found to be of less sweet, while $50 / 60 / 70^{\circ} \mathrm{B}$ was found to be too sweet. Even the tomato candies prepared with $40 \%$ sugar solution was more acceptable than candy with $50 \%$ and $60 \%$ sugar as reported by Hasanuzzaman et al., (2014).

In this study, $40 / 50 / 60^{\circ} \mathrm{B}$ sugar concentration was found to yield optimum sweetness with maximum water removal and good sensory attributes. Hence, it was taken for further quality analysis.

\section{Nutritional composition of baby corn candy}

The nutritional composition of baby corn candy is depicted in Table 1 . The baby corn candy contained calcium (24 mg), magnesium (85.33 $\mathrm{mg})$, iron $(0.23 \mathrm{mg}$ ) and phosphorus $(64.13 \mathrm{mg})$. Similar observations for nutritional composition of jack fruit candy were recorded by Sreedevi et al., (2012) and Sharma et al., (2006). 
Fig.1 Osmotic dehydration characteristics of rectangular baby corn in different sugar concentrations

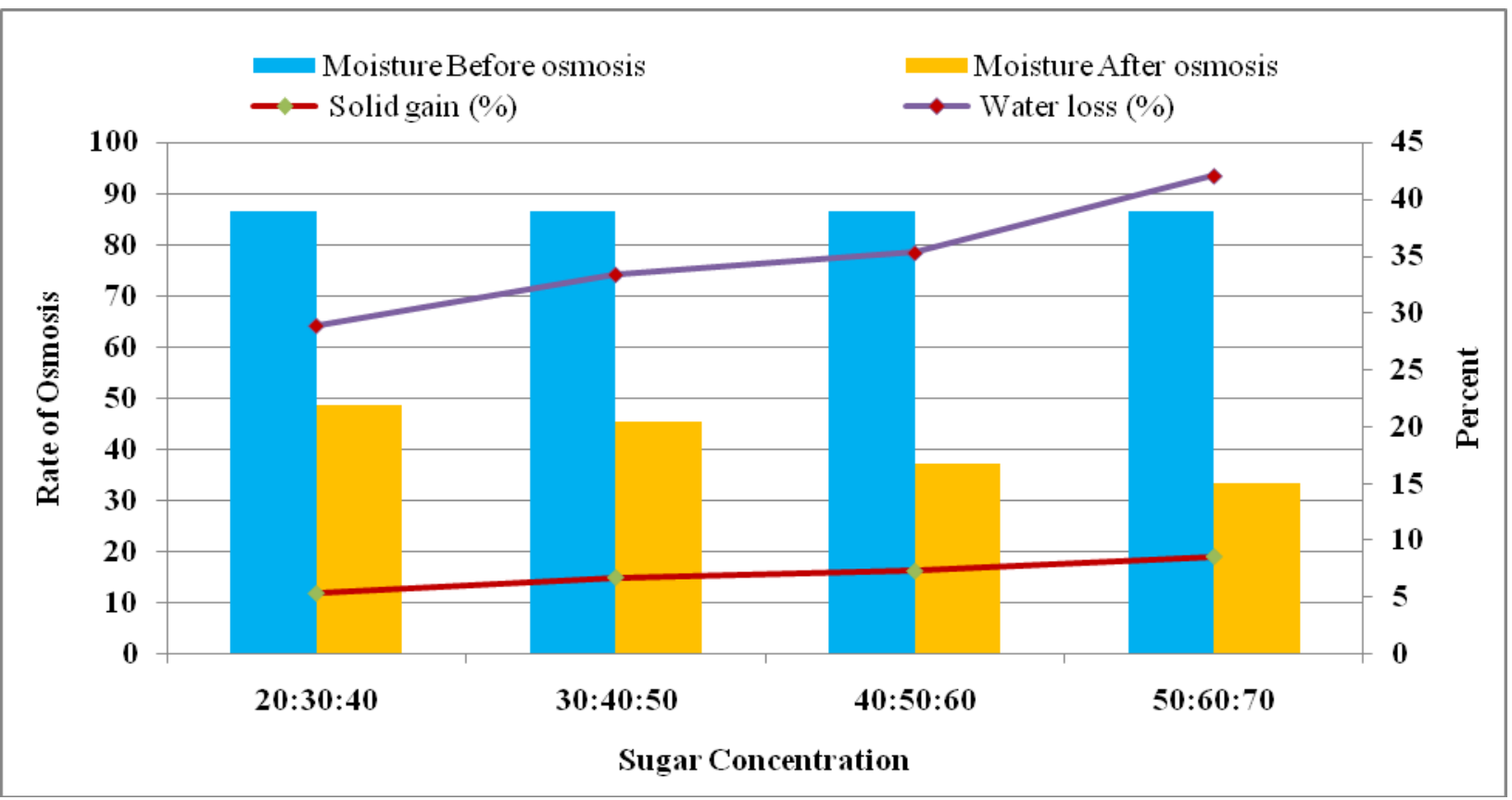

Fig.2 Biochemical changes of rectangular and whole baby corn candies during storage
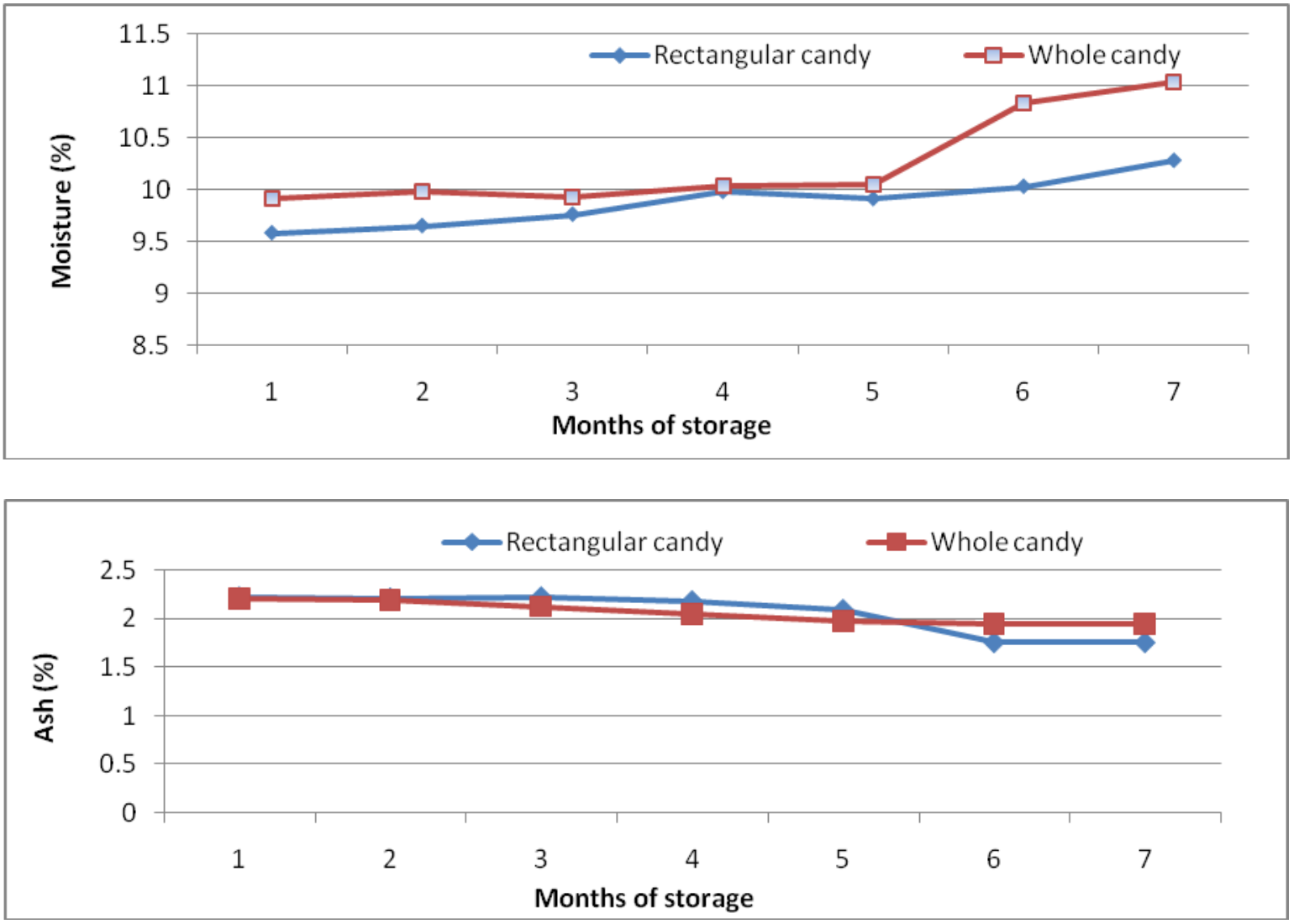
Int.J.Curr.Microbiol.App.Sci (2018) 7(3): 2261-2272
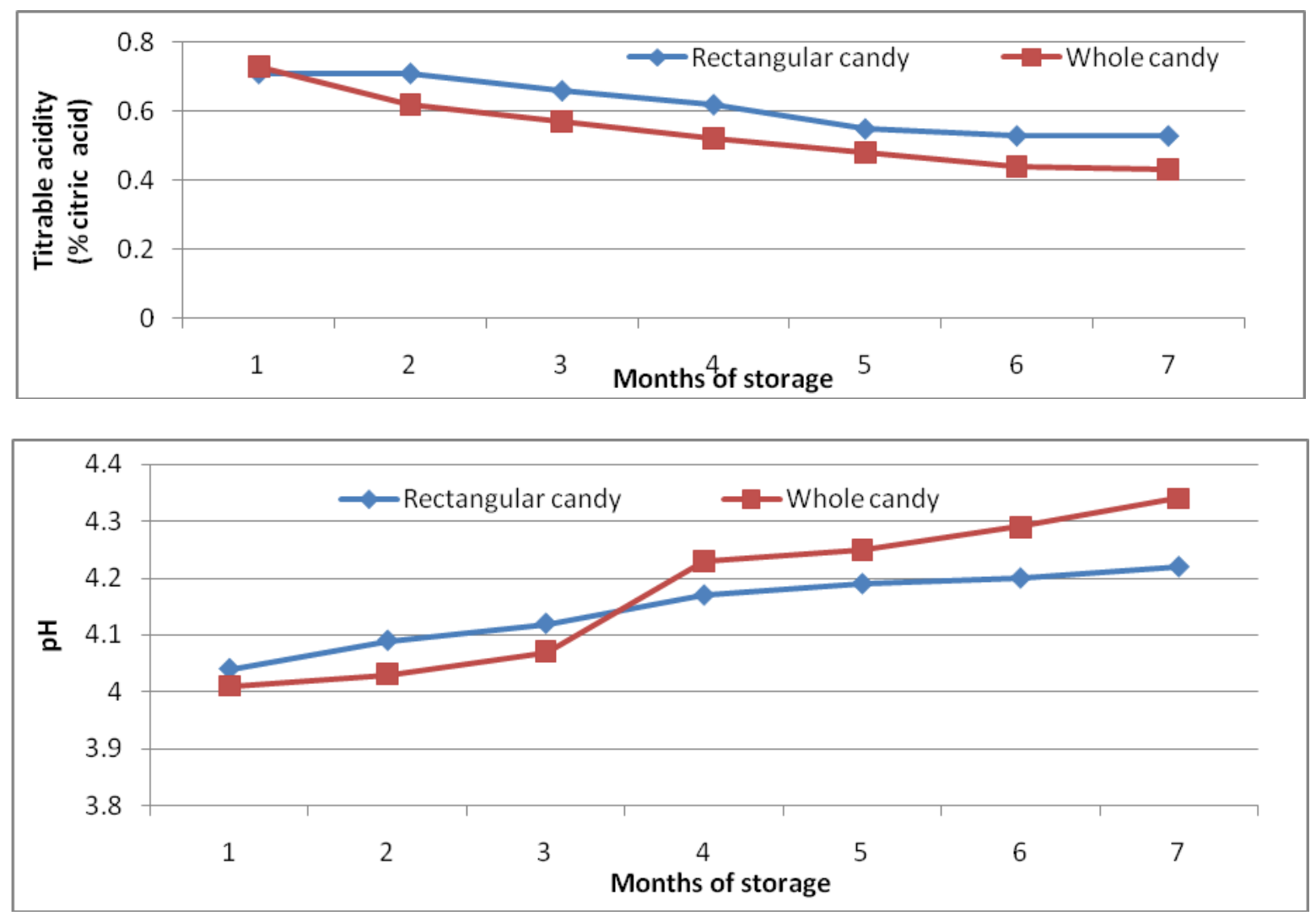

a- Whole candy and b- Rectangular candy

Fig.3 Sensory scores of candies during storage period

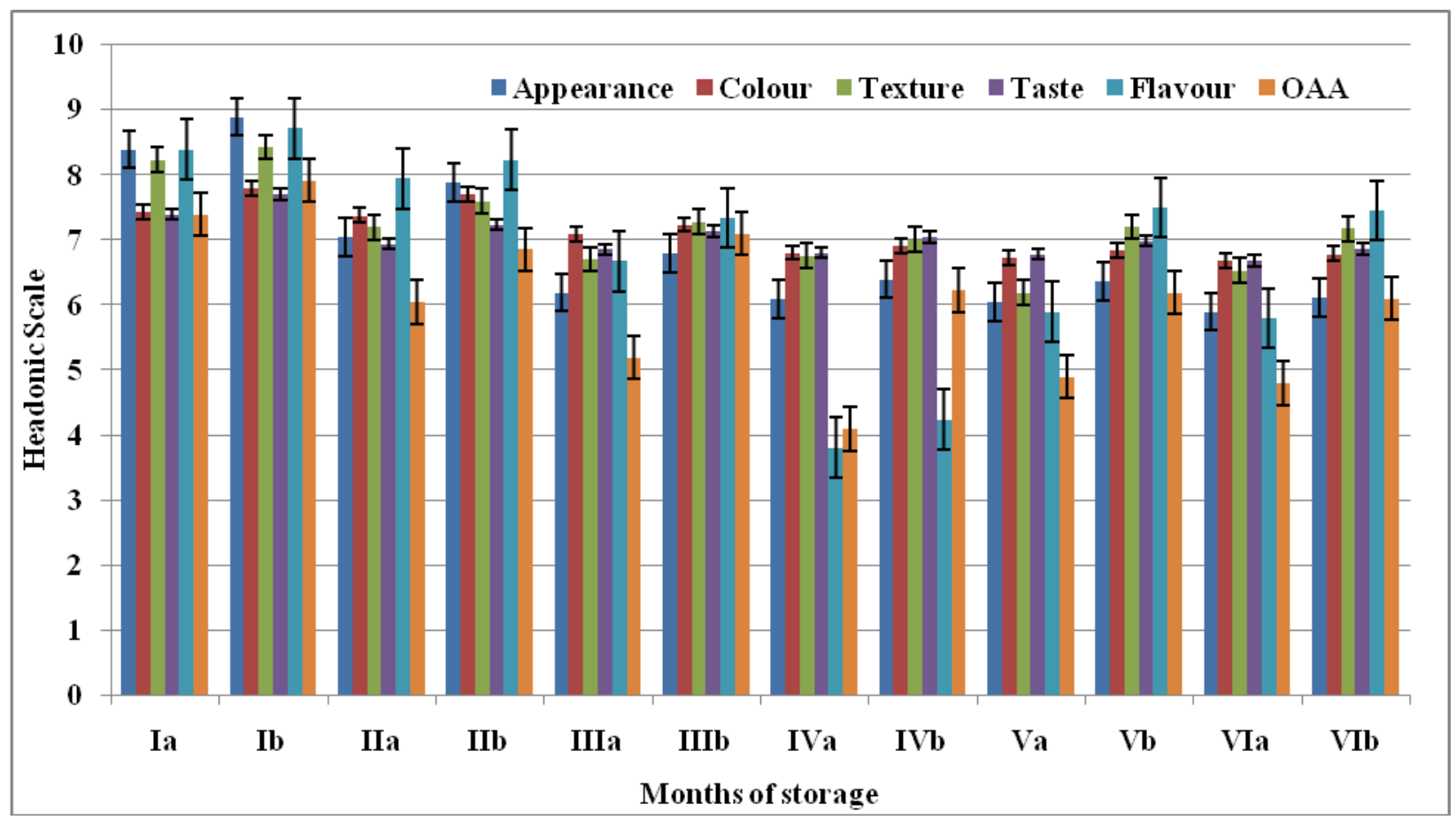


Table.1 Nutritional composition of fresh baby corn (dehusked) and baby corn candy

\begin{tabular}{|l|c|c|}
\multicolumn{1}{|c|}{$\begin{array}{c}\text { Parameters (/ } \\
\text { 100g) }\end{array}$} & $\begin{array}{c}\text { Fresh baby } \\
\text { corn } \\
\text { (dehusked) }\end{array}$ & $\begin{array}{c}\text { Baby corn } \\
\text { candy }\end{array}$ \\
\hline Moisture (\%) & $86.41 \pm 0.52$ & $9.01 \pm 0.30$ \\
\hline Crude Protein (\%) & $2.90 \pm 0.02$ & $1.93 \pm 0.01$ \\
\hline Crude fat (\%) & $0.90 \pm 0.01$ & $0.50 \pm 0.19$ \\
\hline Crude fiber (\%) & $3.42 \pm 0.02$ & $1.95 \pm 0.04$ \\
\hline Ash (\%) & $1.34 \pm 0.02$ & $2.20 \pm 0.02$ \\
\hline Carbohydrates & $9.13 \pm 0.08$ & $86.00 \pm 0.30$ \\
\hline \%) & $25.77 \pm 1.55$ & $24.0 \pm 0.57$ \\
\hline Calcium (mg) & $85.87 \pm 0.50$ & $85.33 \pm 0.52$ \\
\hline Magnesium (mg) & $84.10 \pm 0.91$ & $64.13 \pm 0.34$ \\
\hline Phosphorus (mg) & $0.32 \pm 0.02$ & $0.23 \pm 0.01$ \\
\hline Iron (mg) & $56.55 \pm 0.97$ & $359 \pm 0.50$ \\
\hline Energy (K.cal)
\end{tabular}

Values are mean of three replications \pm SD

Table.2 Effect of different sugar concentrations on sensory attributes of baby corn candies

\begin{tabular}{|c|c|c|c|c|c|c|}
\hline & \multicolumn{7}{|c|}{ Sensory parameters } \\
\hline Treatments & Appearance & Colour & Taste & Flavour & Texture & $\begin{array}{c}\text { Overall } \\
\text { acceptability }\end{array}$ \\
\hline T1 & 4.0 & 4.1 & 2.7 & 3.43 & 3.0 & 3.0 \\
\hline T2 & 3.8 & 3.0 & 2.7 & 2.8 & 2.8 & 2.7 \\
\hline T3 & 4.9 & 4.7 & 4.5 & 4.6 & 4.5 & 4.1 \\
\hline T4 & 4.6 & 5.0 & 3.9 & 4.13 & 3.9 & 3.7 \\
\hline T5 & 7.25 & 6.8 & 6.7 & 7.0 & 6.8 & 7.0 \\
\hline T6 & 8.25 & 8.3 & 8.5 & 8.87 & 8.3 & 8.2 \\
\hline T7 & 6.08 & 6.25 & 5.0 & 5.63 & 5.0 & 4.8 \\
\hline T8 & 5.5 & 5.6 & 4.5 & 4.37 & 4.4 & 4.7 \\
\hline Mean & 5.5 & 5.51 & 4.8 & 5.77 & 4.8 & 4.8 \\
\hline F-Value & $18.22 *$ & $22.52 *$ & $23.49 *$ & $19.64 *$ & $22.62^{*}$ & 35.34 \\
\hline SEm \pm & 0.36 & 0.34 & 0.4 & 0.43 & 0.39 & 0.32 \\
\hline CD at 5\% & 1.08 & 0.97 & 1.13 & 1.29 & 1.11 & 0.91 \\
\hline
\end{tabular}

$\mathrm{T}_{1}: \mathrm{WC}\left(20: 30: 40^{\circ} \mathrm{B}\right), \mathrm{T}_{2}: \mathrm{RC}\left(20: 30: 40^{\circ} \mathrm{B}\right), \mathrm{T}_{3}: \mathrm{WC}\left(30: 40: 50^{\circ} \mathrm{B}\right), \mathrm{T}_{4}: \mathrm{RC}\left(30: 40: 50^{\circ} \mathrm{B}\right), \mathrm{T}_{5}: \mathrm{WC}\left(40: 50: 60^{\circ} \mathrm{B}\right)$, $\mathrm{T}_{6}: \mathrm{RC}\left(40: 50: 60^{\circ} \mathrm{B}\right), \mathrm{T}_{7}: \mathrm{WC}\left(50: 60: 70^{\circ} \mathrm{B}\right), \mathrm{T}_{8}: \mathrm{RC}\left(50: 60: 70^{\circ} \mathrm{B}\right)$

* Significant at $5 \%$ 
Table.3 Nutritional changes of rectangular baby corn candy during storage

\begin{tabular}{|c|c|c|c|c|c|c|c|c|c|c|c|}
\hline \multirow[t]{2}{*}{ Parameters } & \multicolumn{7}{|c|}{ Months of storage } & \multirow[t]{2}{*}{ Mean } & \multirow{2}{*}{$\begin{array}{l}\text { F- } \\
\text { value }\end{array}$} & \multirow[t]{2}{*}{ SEm \pm} & \multirow[t]{2}{*}{ CD } \\
\hline & 0 & I & II & III & IV & $\mathrm{V}$ & VI & & & & \\
\hline Moisture (\%) & 9.20 & 9.25 & 9.30 & 9.50 & & 9.80 & 10.04 & 9.53 & * & 0.053 & 0.162 \\
\hline Fat & 0.66 & 0.5 & 0.51 & 0.48 & 0.43 & 0.38 & 033 & 0.48 & * & & 0.162 \\
\hline Fibe & 3.87 & 3.7 & 3.58 & 3.49 & 3.32 & 3.18 & .9 & 3.45 & $*$ & 53 & 0.191 \\
\hline Prote & 2.02 & 1.99 & 1.98 & 1.97 & 1.96 & 1.9 & 1.9 & 1.97 & NS & 3 & 0.162 \\
\hline Calci & 2.42 & 2.40 & 2.39 & 2.37 & 2. & 2.3 & & 2.37 & NS & 0.058 & 0.175 \\
\hline Magne & 88.00 & 87.90 & 87.40 & 86.70 & 85.80 & 85.20 & 84. & 86.56 & * & 0.577 & 1.751 \\
\hline Iron & 0.32 & & 0.27 & 0.26 & & 0.2 & & 0.27 & NS & 0.058 & 0.175 \\
\hline Phosphor & 69.30 & 68.50 & 67.20 & 66.80 & 66.60 & 66.40 & 66.2 & 67.29 & * & 0.069 & 0.20 \\
\hline Vitamin C & 6.86 & 6.60 & 6.43 & 5.92 & 5.54 & 5.28 & 5.24 & 5.98 & * & 0.076 & 0.23 \\
\hline
\end{tabular}

* Significant at 5\%, NS: Non significant

Biochemical changes of rectangular and whole baby corn candies during storage

The effect of storage on biochemical quality of baby corn candies is depicted in Figure 2 . Increase in moisture, decrease in ash and titrable acidity was noticed in both types of candies, which was not significant. The increase in moisture content was due to permeability of MPP pouches to the air, as well as entrapment of air during sealing and handling. Even the studies of Sagar and Khurdiya (1999), Sharma et al., (2000) and Sharma et al., (2006) in dehydrated mango slices, dried apples and dehydrated apple rings recorded similar patterns of moisture increase during storage. Increase in $\mathrm{pH}$ (4.04 to 4.22 in $\mathrm{RC}, 4.01$ to 4.34 in $\mathrm{WC}$ ) was recorded during storage. The biochemical changes in baby corn candies of two shapes showed similar pattern, since the osmotic treatment, method of preparation and drying followed were similar for both the candy types, indicating non-significant difference between the products over a period of six months biochemically. Similar line of work on storage of osmotically dehydrated apricots in polythene pouch, glass jars and laminated pouches over 6 months at $13-28^{\circ} \mathrm{C}$ showed that laminated pouches were found to be the best packaging material with a minimum change in chemical composition and sensory attributes (Sharma et al., 2000).

\section{Sensory quality of baby corn candy during storage}

The candies prepared from $40 / 50 / 60^{\circ} \mathrm{B}$ syrup stored in MPP pouches showed significant changes in sensory quality with respect to months (Fig. 3) when evaluated for acceptability during storage. The appearance scores decreased from 8.4 to 5.9 in WC and 8.9 to 6.12 in $\mathrm{RC}$ indicating that the $\mathrm{RC}$ scored between "slightly acceptable" to "moderately acceptable" at the end of storage period. There was no change in colour of both the candies (Fig. 3). However, texture (8.24 to 6.54 ), taste (7.4 to 6.69), flavor (8.4 to 5.8) and overall acceptability (7.4 to 4.8) scores of WC decreased significantly compared to RC during storage which was due to size of the WC contributed to uneven drying which in turn significantly affected the texture and taste parameters. The overall acceptability of $\mathrm{RC}$ was in the range of "moderately acceptable" to "like very much". Decrease in sensory scores of baby corn candy during storage might be due to the aging of the product. Sreedevi et al., (2012), Hiremath and Rokhade (2012), Chavan et al., (2010) also reported similar results in jack fruit candy, 
sapota candy and osmo-dried banana slices, respectively. Decrease in sensory scores during storage of apricots was noticed by Sharma et al., (2000), which might be due to the reduction of $\mathrm{SO}_{2}$ and increase of moisture in samples attributing to non-enzymatic browning, oxidation and changes in other chemical constituents of the product.

\section{Nutritional changes of baby corn candy}

Since non-significant changes were observed between two types of candies in bio-chemical and sensory parameters. RC scored fairly well during storage. Therefore, RC was taken for nutritional analysis. The changes in the nutritional content of baby corn candy are depicted in (Table 3). Significant changes in moisture, fat, fiber, magnesium, phosphorus and Vitamin $\mathrm{C}$ content was noticed during storage (Table 3). This was due to higher sugar addition leads to more water molecules to move out of the material and water to dissolve some of the nutrients and Vitamin C. Similar trend of decrease in ascorbic acid content was reported for guava candy by Kannan and Thirumaran (2002). Nonsignificant changes were observed in major nutrients and mineral content of baby corn candy during storage was observed in the study.

\section{Microbial quality of baby corn candy during storage}

The fungi $\left(0.65\right.$ to $\left.1.18 \times 10^{2}\right)$ and bacterial counts $\left(0.15\right.$ to $\left.2.17 \times 10^{3}\right)$ increased during storage, while no mould growth was noticed till the end of three months. Bacterial colonies noticed were found to be gram negative. The preservatives like citric acid and KMS added during candy preparation might have prevented the excessive growth of microbes; on the other hand the microbial counts noticed in this study might be due to the contamination occurred during handling.
Similar microbial load in osmo-dehydrated candies was reported by Manimegalai et al., (2001) in jackfruit bar, Chavan et al., (2010) in osmo banana slices, Sreedevi et al., (2012) in jackfruit candy and Hasanuzzaman et al., (2014) for tomato candy.

\section{Consumer acceptability of the candy}

It was observed that the maximum number $(82.2 \%)$ of consumers rated the RC as "very good" followed by good (11.1\%) and not good $(6.6 \%)$ in three different locations.

Baby corns of rectangular pieces were successfully osmotically-dehydrated by $40 / 50 / 60^{\circ} \mathrm{B}$ sugar concentration, dried at $60^{\circ} \mathrm{C}$ for $8 \mathrm{hrs}$ and stored in MPP pouches. The rectangular candies were adjudged best due to acceptable sensory attributes of colour, appearance, flavor, taste, texture, overall acceptability and their ability to retain higher percentage of nutrients. This study will help the food producer or the confectionary manufacturer to select the appropriate concentration of sugar solution for making baby corn candy and at the same time shelf life of fresh baby corns can be extended by preserving them through nutritious candy preparation.

Conflict of Interest: None declared

\section{References}

Aggarwal P, Kaur R. (2010). Steeping preservation of baby corn. Int $J$ of vegetable Sci., 16:103-117.

Amerine M.D. Pangborn P.M. and Roessler E.B. (1965). Principles of sensory evaluation of food. Academic press, New york, pp 350-480

Anuradha M.(2012). Maize-The Miracle Crop. Maize Research Centre, ANGRAU, Hyderabad, pp 91. 
AOAC (1995). Official methods of analysis, 16th edn. Association of Official Analytical Chemists, Washington.

APHA(1984). In: Speak ML (ed) Compendium of methods for the microbiological analysis of food. American Public Health Association, Washington.

Asaduzzaman, M., Biswas, M., Islam M.N., Rahman M.M., Begum R.and Sarkar, M.A.R. (2014). Variety and N-fertilizer rate influence the growth, yield and yield parameters of baby corn (Zea mays L.). J Agric Sci., 6(3): 118-131.

Azoubel, P.M. and Murr F.E.X. (2003). Optimisation of Osmotic Dehydration of Cashew Apple (Anacardium occidentale L.) in Sugar Solutions. Food Sci Techol Int., 9(6):0427-7.

Biswal, R.N. and Bozorgmehr, K. (1991). Equilibrium data for osmotic concentration of potato in nacl-water solution. J Food Proc Eng., 14:237-245.

Chavan, U.D., Prabhukhanolkar, A.E. and Pawar, V.D. (2010). Preparation of osmotic dehydrated ripe banana slices. $J$ Food Sci Technol., 47(4): 380-386.

Chenlo, F., Moreira, R., Pereira, G. and Ampudia, A. (2002). Viscosities of aqueous solutions of sucrose and sodium chloride of interest in osmotic dehydration processes. $J$ of Food Eng v., 54(4), p 347-352 2002. http:// dx.doi. org/10.1016/S0260-8774(01):00221-7

Hasanuzzaman, M., Kamruzzaman, M., Islam M.M., Khanom S.A.A., Rahman M.M., Lisa, L.A. and Paul D.K. (2014). A Study on Tomato Candy Prepared by Dehydration Technique Using Different Sugar Solutions. Food Nutr Sci., 5:1261-1271.

Hiremath J.B. and Rokhad A.K. (2012). Preparation of sapota candy. Int $J$ food Agric and Veterinary Sci., 2(1):107-112
Kannan, S. and Thirumaran A.S. (2002). Effect of osmotic dehydration of guava. S Indian Hort., 50: 195-199.

Kapoor, M. (2002). Exploibabycornpotential. http://www,tribune.com/2002/2002090 9/ agro.htm. Assessed on 3 June 2017

Kawatra, A. and Sehgal, S. (2007). Valueadded products of maize (Quality Protein Maize and Baby Corn). National conference on "Double Maize Production" organized by IFFCO Foundation, ICAR, DMR, DAC \& IFFCL at New Delhi on May 08-09, 2007.

Kheibari, M.K., Khorasani S.K. and Taheri, G. (2012). Effects of plant density and variety on some of morphological traits, yield and yield components of baby corn (Zea mays L.). Intl Res J Appl Basic Sci., 3(10): 2009-2014.

Lekagul, T. (1994). Prospects of baby corn production in Nepal. Report prepared for Agro-Enterprise Centre/FNCCI and USAID/Nepal. Chemonics International Consulting Division, 2000 M Street, Washington D. C., USA.

Livesey,G.(2001). A perspective on food energy standards for nutrition labelling. British $J$ of Nutri, 85: 271287.

Manimegalai,G., Krishnaveni, A. and Saravanakumar, R.(2001). Processing and preservation of jackfruit bar. J Food Sci Technol., 38(5):529-531.

Patil, B.N., Gupta, S.V., Patil, N.B., Borkar, N.T. and Naveen, M. (2015). Optimization of osmotically dehydrated ginger candy using response surface methodology. Intrl $J$ Agric Sci., 7(14):858-862.

Paul, P.K., Ghosh, S.K., Singh, D.K. and Bhowmick, N. (2014). Quality of osmotically pre-treated and vacuum dried pineapple cubes on storage as influenced by type of solutes and 
packaging materials. $J$ Food Sci Technol., 51(8):1561-1567.

Pokharkar, S.M., Prasad, S.and Das, H. (1997). A model for osmotic concentration of banana slices. J Food Sci Technol., 34(3):230-232.

Ranganna, S. (2001). Handbook of analysis and quality control for fruit and vegetable products, 2nd edn. TataMcGraw-Hill Publishing Company Limited, New Delhi, pp 105-106.

Sagar, V.R., Kumar, R. (2006). Preparation and storage study of ready-to eat dehydrated gooseberry (aonla) shreds. $J$ Food Sci Technol., 43:349-352.

Sagar, V.S., Khurdiya, D.S. (1999). Studies on dehydration of Dashehari mango slices. Indian Food Pack., 53(1):5-9.

Sethi, V. (1986). Effect of blanching on drying of aonla. Indian Food Pack., 40(4):7-10.

Sharma, K.D., Alkesh., Kaushal, B.B.L. (2006). Evaluation of apple cultivars for dehydration. $J$ Food Sci Technol., 43(2):177-181.

Sharma, K.D., Rajesh Kumar., Lal Kaushal, B.B. (2000). Effect of packaging on quality and shelf-life of osmo-air dried apricot. J Sci Ind Res., 59:949-954.

Silva, M.A.C., Da Silva, Z.E. and Mariani, V.C. (2012). Mass transfer during the osmotic dehydration of West Indian cherry Food Sci Techno., 45:246-252.

Singh, B., Parmjit Panesar, S. and Nanda,V.(2007). Rehydration Kinetics of Un-Osmosed and Pre-Osmosed Carrot Cubes. World J Dairy Food Sci., 2(1):10-17.

Singh, R., Dashora, L.K. and Upadhyay, B. (2006b). Effect of pre-drying treatments and drying methods on physiconutritional quality of dehydrated aonla shreds. Indian Food Pack, 60(3): 57-63.

Sreedevi, M.S., Palanimuthu, V., Nagaraja, G. and Ragupathi, C.J. (2012). Development and standardization of recipe for jackfruit candy. Int $J$ Process Post harvest technol., 3(1): 73-76.

Steel, R.G.A., Torrie, J.H., Dickey, D.A. (1997). Principles and procedures of statistics; a biometrical approach, 3rd edn. McGraw Hill Book Co.Inc, New York, pp 400-428.

Thakor, N.J., Sawant, A.A. (2008). Effect of sucrose concentration and temperature on osmotic dehydration of pineapple slices. Agric Update., 3(3\&4): 417-420.

Tripathi, V.K., Singh, B.M. and Singh, S. (1988). Studies on comparative composition changes in different preserved product of aonla. Indian Food Pack., 42(4): 60-66.

\section{How to cite this article:}

Shobha, D., M.S. Sreedevi and Puttaramanaik. 2018. Baby Corn Candy: Development and Assessment of Nutritional, Sensory and Storage Quality. Int.J.Curr.Microbiol.App.Sci. 7(03): 2261-2272. doi: https://doi.org/10.20546/ijcmas.2018.703.266 